\title{
Keefektifan Konseling Rational Emotive Behaviour Teknik Cognitive Disputation untuk Mengurangi Tingkat Fanatisme terhadap Idola pada Siswa Penggemar K-Pop
}

\author{
Nandita Aprilias ${ }^{1}$, Bambang Dibyo Wiyono ${ }^{2}$ \\ Jurusan Bimbingan dan Konseling, Fakultas Ilmu Pendidikan, Universitas \\ Negeri Surabaya ${ }^{1, \& 2}$ \\ Email: nanditaaprilias@mhs.unesa.ac.id ${ }^{1}$,bambangwiyono@unesa.ac.id ${ }^{2}$
}

\begin{abstract}
:
Behavior of K-Pop fans in grade 12th science 3 of State Boarding Aliyah 2 Gresik, leads to behaviour of fanaical fans. The purpose of this research is to know the effectiveness of rational emotive behavior counseling with a pre-test post- test one group design. The instrument of this research is questionnaire of idol fanatiscm for K-Pop fans. The subject of this research is $3 \mathrm{~K}$-Pop fans students from grade $12^{\wedge}$ th science 3 who have a high level of fanatiscm, based on the pre-test result. Analysis technique that used in this research is paired sample $t$ test. Based on calculation, obtained Asmp. Sig (2 tailed $)=0,015$. According to the basic of decision, H_a accepted if Asmp. Sig (2 tailed) <0,05. Because of Asmp. Sig 0, $015<0,05$, the H_a accepted, and that means there is a difference between before and after of rational emotive behavior counseling implementation. So, it can be concluded that counseling rational emotive behavior with cognitive disputation technique is effective for reduce idol fanaticism of K-Pop fans students.
\end{abstract}

Keyword: rational emotive behavior counseling, cognitive disputation technique, idol fanaticism, fans k-pop

Received August 20, 2019; Revised September 27, 2019; Accepted October 1, 2019

How to Cite: Aprilias, N., Wiyono, B. D. (2019). Keefektifan Konseling Rational Emotive Behaviour Teknik Cognitive Disputation untuk Mengurangi Tingkat Fanatisme terhadap Idola pada Siswa Penggemar K-Pop. JKI (Jurnal Konseling Indonesia), 5(1), 12-20.

This is an open access article distributed under the Creative Commons 4.0 Attribution License, which permits unrestricted use, distribution, and reproduction in any medium, provided the original work is properly cited. @2019 by author and Guidance and Counseling Program of Faculty of Education Sciences Universitas Kanjuruhan Malang.

\section{PENDAHULUAN}

Salah satu penggemar yang terkenal, khususnya di indonesia adalah penggemar K-Pop (Korean Music Pop) yang sering disebut K-Popers (Korean Music Pop Lovers). Menurut Nugraini dalam Eliani (2018) K-Pop adalah suatu aliran music yang merupakan gabungan dari genre musik lain, dan dipopulerkan oleh sekelompok laki-laki maupun sekelompok perempuan yang sering disebut boyband dan girlband. Umumnya penggemar K-Pop di dominasi oleh kaum remaja. Seperti pendapat Wijayanti dalam Pertiwi (2013) yang mengatakan bahwa yang terkena imbas dari fenomena Korean Wave (penyebaran budaya Korea secara mendunia) di Indonesia adalah para remaja, yang umumnya menggemari drama Korea dan musik pop Korea (K-Pop). Banyaknya K-Popers dari kalangan remaja terjadi bukan tanpa alasan. Seperti yang diungkapkan oleh Dariyo dalam Kurniati (2015) yang mengatakan bahwa remaja sangat mudah dipengaruhi oleh arus perkembangan zaman. Kaitannya dengan 
pendapat tersebut, kehidupan remaja saat ini tidak bisa dilepaskan dari internet. Sementara K-Pop sendiri disebarkan lewat perantara internet. Adanya intenet secara tidak langsung memudahkan para remaja mengenal $K$-Pop dan dimulai dari sanalah kegemaran pada K-Pop dimulai.

Para penggemar K-Pop pada umumnya tidak hanya menyukai $K$-Pop dari segi musiknya saja. Tetapi, banyak dari mereka yang menyukai bahkan tergila-gila pada member (anggota) boyband maupun girlband yang mempopulerkan musik K-Pop itu sendiri. Hal ini terjadi karena menurut Yusuf (2014) perasaan atau emosi pada remaja mulai berkembang. Remaja mulai merasakan perasaan seperti perasaan cinta, rindu dan keinginan untuk mengenal lawan jenis secara lebih dalam. Selaras dengan pendapat tersebut, umumnya penggemar $K$-Pop dari kalangan remaja perempuan lebih menyukai anggota boyband, sementara penggemar $K$-Pop dari remaja laki-laki lebih cenderung menyukai anggota girlband.

Menggemari K-Pop maupun boyband dan girlband yang mempopulerkannya, sebenarnya bukanlah sebuah kesalahan. Hal itu sah-sah saja dilakukan oleh setiap individu atau bahkan setiap remaja di dunia. Namun, yang dikhawatirkan di sini adalah, ketika kegemaran tersebut malah memberikan dampak yang negatif bagi diri dan kehidupan remaja. Salah satu dampak negatif yang biasanya dialami oleh penggemar $K$-Pop adalah fanatisme terhadap idola. Menurut Goddard dalam Eliani (2018), fanatisme dimaknai sebagai keyakinan yang begitu kuat hingga membuat seseorang rela melakukan segalanya untuk mempertahankan keyakinan tersebut. Sementara idola menurut Nurhadi, dkk dalam Gafar (2014) diartikan sebagai tokoh atau seseorang yang dikagumi.

Berdasarkan studi pendahuluan yang dilakukan dengan menggunakan metode observasi dan wawancara, peneliti bertemu dengan beberapa siswi penggemar K-Pop yang perilakunya cenderung berlebihan dalam menggemari idolanya. Hal ini bermula pada saat peneliti berkesempatan untuk mengisi jam kosong di salah satu kelas XII. Saat memasuki kelas tersebut, peneliti mendengar alunan sebuah lagu yang dipopulerkan oleh salah satu boyband kenamaan Korea, serta suara beberapa siswi yang ikut menyanyikan lagu tersebut secara serempak. Setelah dikonfirmasi, ternyata memang benar bahwa di kelas tersebut terdapat cukup banyak siswi penggemar $K$ Pop. Aktivitas seperti itu sering dilakukan. Sekalipun teman-teman yang bukan penggemar $K$-Pop merasa terganggu, namun para siswi penggemar K-Pop tersebut nampaknya tidak perduli.

Mengetahui fakta di atas, peneliti berinisiatif untuk melakukan wawancara dengan lima orang siswi dari beberapa siswi penggemar K-Pop di kelas tersebut. Wawancara dilakukan untuk mendapatkan informasi yang lebih detail berkaitan dengan kegemaran para siswi terhadap K-Pop. Berdasarkan hasil wawancara yang telah dilakukan, beberapa diantaranya diketahui memiliki kecenderungan menggemari idolanya secara berlebihan. Seperti siswi yang berinisial DR, yang tidak suka bahkan mengatakan sangat sedih apabila idolanya berpacaran dengan artis lain. DR mengatakan "Aku kepikiran buat ninggalin $K$-Pop kak, soalnya biasku (idola) udah dating (pacaran). Aku gak suka kalau idolaku pacaran. Ketimbang aku nangis, teriak-teriak gak jelas, mendingan aku mundur."

Selain itu, beberapa siswi yang lain menuturkan bahwa dirinya pernah beberapa kali bertengkar dengan hatters di sosial media atau bahkan dengan temannya sendiri apabila idolanya dihina. Seperti yang diungkapkan oleh subjek ES yang mengatakan, "Iya saya pernah berantem sampe adu mulut malah, sama temen sekelas saya yang ngehina idola saya, kak". Sementara subjek SK mengatakan bahwa "Saya sering tersinggung kak, kalau idola dibully. Saya pernah ngejelasin ke mereka yang nge-bully kalau idola saya enggak kayak gitu, tapi kadang percuma, jadi akhirnya saya abaikan saja."

Kecintaan terhadap idola K-Pop juga ditunjukkan dengan sikap yang tidak berkeberatan menghabiskan uang untuk membeli pernak-pernik seperti poster idola, majalah, album, bahkan kuota internet untuk mengakses informasi tentang idolanya setiap hari. Berdasarkan hasil wawancara tersebut, maka peneliti menyimpulkan bahwa beberapa siswi penggemar K-Pop yang telah diwawancarai tersebut menunjukkan perilaku fanatik terhadap idolanya. Sebab, siswi yang bersangkutan menggemari idolanya dengan cara yang berlebihan dan tidak biasa. Timbulnya perilaku fanatik ini tidak terlepas dari adanya fanatisme dalam diri siswi yang bersangkutan. Sebab, sebagaimana yang diungkapkan oleh Prakoso (2013) fanatik adalah sikap yang timbul saat seseorang memiliki fanatisme atau faham fanatik dalam dirinya.

Fanatisme terhadap idola yang dimiliki oleh para siswi ini tidak bisa dibiarkan terus-menerus, karena apabila tidak diarahkan kepada sesuatu hal yang benar, maka dapat menyebabkan munculnya perilaku negatif. Seperti yang diungkapkan oleh Marimaa dalam Eliani (2018) yang mengatakan bahwa ketika fanatisme semakin berkembang dan menguat dalam diri individu, maka besar kemungkinan akan menyebabkan timbulnya perilaku yang negatif, salah satunya adalah perilaku agresif. Eliani (2018) dalam penelitiannya mengatakan bahwa fanatisme merupakan penyebab timbulnya perilaku agresif verbal di sosial media yang dilakukan oleh penggemar K-Pop. Selain agresif verbal, fanatisme juga bisa menyebabkan perilaku agresif fisik, seperti yang dilakukan oleh para suporter sepak bola beberapa waktu terakhir, yang mana sampai menimbulkan korban jiwa.

Mubarok (2006) berpendapat bahwa fanatisme dalam diri seseorang dapat menghilang apabila orang tersebut sudah dapat berpikir secara rasional. Sebab menurutnya orang yang fanatik cenderung berpikiran irasional terhadap apa yang diyakininya benar. Berdasarkan pendapat Mubarrok tersebut, maka dapat 
disimpulkan bahwa untuk dapat menurunkan atau bahkan menghilangkan fanatisme idola dalam diri penggemar $K$-Pop, salah satu upaya yang bisa dilakukan adalah dengan mengubah pikiran irasional yang dimiliki penggemar $K$-Pop tentang idolanya menjadi pikiran yang lebih rasional.

Salah satu pendekatan dalam konseling yang dapat digunakan untuk mengubah pikiran irasional seseorang menjadi pikiran rasional, adalah pendekatan REBT (Rational Emotive Behaviour). Menurut Ellis dan Dryden dalam Fitriani (2016) konseling rational emotive behaviour adalah konseling yang dilakukan untuk membantu individu mengubah pikiran irasionalnya yang mana merupakan penyebab timbulnya permasalahan, menjadi pemikiran yang lebih rasional. Perilaku fanatik yang ditunjukkan oleh siswa penggemar $K$-Pop besar kemungkinannya disebabkan oleh pikiran yang irasional tentang idolanya. Oleh karena itulah pikiran irasional tersebut harus diidentifikasi dan dirubah. Salah satu caranya adalah dengan melalui kegiatan konseling rational emotive behaviour, sebab konseling ini berfokus pada kegiatan merubah pikiran irasional individu menjadi pikiran yang rasional. Konseling Rational Emotive Behaviour dalam pelaksanaannya memiliki banyak teknik yang bisa digunakan untuk mengubah pikiran irasional konseli. Salah satunya adalah teknik cognitive disputation. Teknik ini dilakukan dengan cara mengajukan pertanyaan-pertanyaan yang tujuannya untuk mendebat pikiran irasional konseli (Komalasari, 2018).

Peneliti sebelumnya, Khulafaurosyidin (2013), melakukan sebuah penelitian dengan menerapkan konseling REP (Rasional Emotif Perilaku) untuk mengurangi tingkat fanatisme terhadap idola yang dialami oleh beberapa siswa di SMPN 6 Tuban. Hasil dari penelitian tersebut, diketahui bahwa dengan menerapkan konseling REP untuk siswa yang fanatik terhadap idolanya, dapat menurunkan tingkat fanatisme yang dialami oleh siswa-siswa tersebut. Berdasarkan hal ini, dapat diketahui bahwa konseling REP yang dalam bahasa Inggris disebut rational emotive behaviour efektif untuk menurunkan tingkat fanatisme idola yang dialami oleh siswa.

Berdasarkan permasalahan yang terjadi, juga pendapat para ahli, serta penelitian yang dilakukan oleh peneliti sebelumnya tentang keefektifan konseling rational emotive behaviour dalam membantu seseorang mengurangi tingkat fanatisme terhadap idola yang dimiliki, maka penulis berkesimpulan bahwa konseling rational emotive behaviour dapat digunakan untuk membantu siswa penggemar $K$-Pop dalam mengurangi tingkat fanatisme yang dimilikinya. Oleh karena itu, peneliti tertarik untuk melakukan sebuah penelitian dengan judul "Keefektifan Konseling Rational Emotive Behaviour dengan Teknik Cognitive Disputation untuk Mengurangi Tingkat Fanatisme terhadap Idola pada Siswa Penggemar K-Pop di MAN 2 Gresik”. Tujuan dari pelaksanaan penelitian ini adalah untuk mengetahui apakah konseling rational emotive behaviour dalam pelaksanaannya dapat mengurangi tingkat fanatisme terhadap idola pada penggemar K-Pop atau tidak.

\section{METODE PENELITIAN}

Pendekatan dalam penelitian ini adalah pendekatan kuantitatif dengan menggunakan metode eksperimen. Bentuk design yang digunakan dalam penelitian ini adalah pre-ekspremental design dengan menggunakan rancangan one group pretest-posttest design. Jenis rancangan ini dipilih sebab hanya terdapat satu kelompok perlakuan. Subjek dalam penelitian ini adalah 3 siswi penggemar $K$-Pop dari kelas XII IPA 3 MAN 2 Gresik yang merupakan penggemar $K$-Pop dan memiliki tingkat fanatisme terhadap idola yang tinggi dalam dirinya. Instrumen yang digunakan dalam penelitian ini berupa angket fanatisme terhadap idola yang disusun berdasarkan pendapat Goddard. Data yang nantinya diperoleh terlebih dahulu diuji normalitasnya. Apabila data diketahui berdistribusi normal, maka teknik analisis data yang digunakan adalah uji paired sample t-test, namun apabila tidak berdistribusi normal maka menggunakan uji Wilcoxon.

\section{HASIL}

Pre-test bertujuan untuk mengetahui kondisi awal subjek penelitian sebelum diberikan perlakuan. Pre-test dilaksanakan dengan menyebarkan angket fanatisme terhadap idola yang telah diuji validitas dan reliabilitasnya kepada siswa kelas XII IPA 3 yang berjumlah 36 siswa. Subjek eksperimen nantinya akan diambil dari ke-36 siswa tersebut, yang mana hasil perhitungan angketnya menunjukkan skor yang tinggi.

Hasil perhitungan angket diperoleh melalui perhitungan dalam microsoft excel dengan pengkategorian yang rendah, sedang dan tinggi. Di bawah ini adalah rumus yang digunakan untuk pengkategorian skor:

$$
\begin{aligned}
\text { a. Kategori Tinggi } & =(\text { Mean }+1 \mathrm{SD}) \text { ke atas } \\
& =(126,722+16,481) \\
& =143,203 \\
\text { b. Kategori sedang } \quad & =(\text { Mean }+1 \mathrm{SD}) \text { sampai }(\text { Mean }+1 \mathrm{SD}) \\
& =(126,722-16,481) \text { sampai }(126,722+16,481)
\end{aligned}
$$




$$
\begin{aligned}
& =(110,240) \text { sampai }(143,203) \\
\text { c. } \quad \text { Kategori rendah } \quad & (\text { Mean }-1 \mathrm{SD}) \text { ke bawah } \\
& =(126,722-16,481) \\
& =110,240
\end{aligned}
$$

Berdasarkan perhitungan angket yang sudah disebar kepada 36 siswa, diketahui bahwa terdapat 3 siswa yang masuk dalam kategori tinggi, 27 siswa masuk dalam kategori sedang, dan sisanya sebanyak 6 siswa masuk ke dalam kategori rendah. Ketiga siswa yang masuk ke dalam kategori tinggi artinya menunjukkan bahwa siswasiswa tersebut memiliki tingkat fanatisme terhadap idola yang tinggi, sehingga ketiganya dijadikan sebagai subjek penelitian. Berikut ketiga siswa yang menjadi subjek penelitian:

Tabel 1

Hasil Pre-test Subjek Penelitian

\begin{tabular}{|c|c|c|c|}
\hline No. & Nama & Jumlah Skor & Kategori \\
\hline 1. & ES & 152 & Tinggi \\
\hline 2. & RS & 173 & Tinggi \\
\hline 3. & SK & 165 & Tinggi \\
\hline
\end{tabular}

Setelah ditentukan subjek penelitian berdasarkan hasil pre-test, maka ketiga subjek kemudian diberikan perlakuan berupa konseling rational emotive behaviour teknik cognitive disputation untuk mengurangi tingkat fanatisme terhadap idola yang dialami oleh subjek. Pemberian perlakuan terhadap masing-masing subjek dilakukan sebanyak 6 kali pertemuan. Setelah pemberian perlakuan rampung dilaksanakan, maka dilakukanlah pos-test dengan memberikan angket fanatisme terhadap idola kepada ketiga subjek. Berikut ini hasil post-test setiap subjek:

Tabel 2

Hasil Post-Test Subjek Penelitian

\begin{tabular}{|c|c|c|c|}
\hline No. & Nama & Jumlah Skor & Kategori \\
\hline 1. & ES & 111 & Sedang \\
\hline 2. & SK & 128 & Sedang \\
\hline 3. & RS & 118 & Sedang \\
\hline
\end{tabular}

Berdasarkan tabel hasil post-test di atas, dapat diketahui bahwa masing-masing subjek penelitian setelah diberikannya perlakuan, mengalami penurunan skor tingkat fanatisme terhadap idola apabila dibandingkan dengan hasil pre-test. Berikut ini adalah perbandingan hasil pre-test dan post-test subjek penelitian:

Tabel 3

Perbandingan Hasil Pre-test dan Post-test

\begin{tabular}{|c|c|c|c|c|c|c|}
\hline No. & Nama & $\begin{array}{r}\text { Pre-test } \\
(\mathbf{X B} \\
)\end{array}$ & $\begin{array}{r}\text { Post-test } \\
(\mathbf{X} \\
\mathbf{A})\end{array}$ & Arah Perbedaan & Tanda & Keterangan \\
\hline 1. & ES & 152 & 111 & XA<XB & - & Menurun \\
\hline 2. & SK & 165 & 128 & XA<XB & - & Menurun \\
\hline 3. & RS & 173 & 119 & XA<XB & - & Menurun \\
\hline \multicolumn{2}{r}{ Rata-Rata } & 163,33 & 119 & & \\
\hline
\end{tabular}

Berikut ini adalah hasil analisis pre-test dan post-test yang disajikan dalam bentuk diagram: 


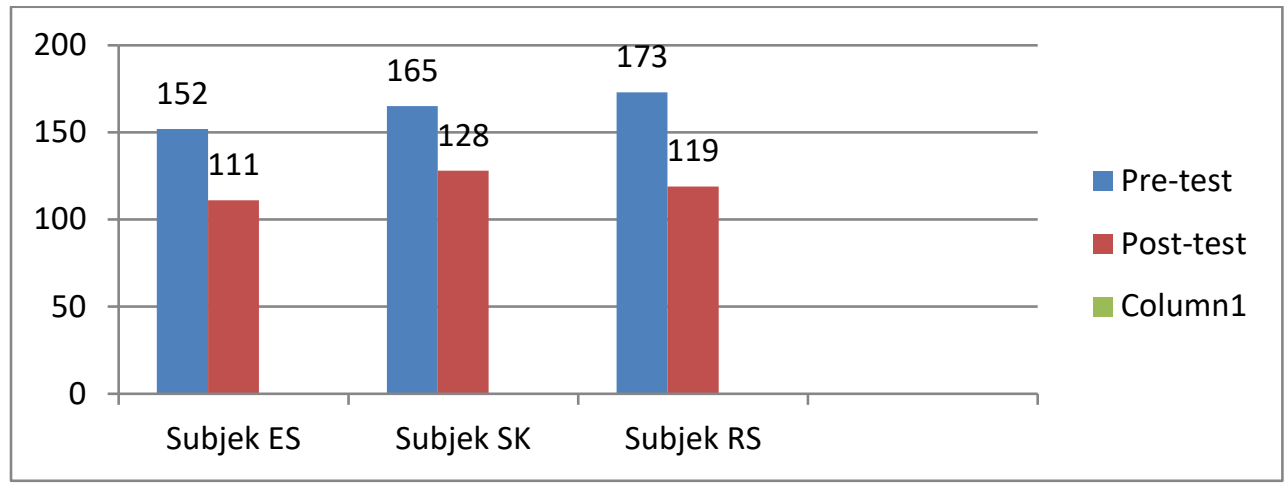

Diagram 1: Perbandingan Hasil Pre-test dan Post-test

Data pre-test dan post-test yang telah didapatkan, kemudian di uji normalitas terlebih dahulu untuk mengetahui apakah data tersebut berdistribusi normal atau tidak. Uji normalitas dalam penelitian ini menggunakan teknik shapiro wilk dan perhitungannya dilakukan dengan menggunakan SPSS 22. Berikut ini hasil uji normalitas yang telah dilakukan:

Tabel 4

Uji Normalitas

\begin{tabular}{|c|c|c|c|}
\hline \multicolumn{4}{|c|}{ Test of Normality } \\
\hline & \multicolumn{3}{|c|}{ Shapiro Wilk } \\
\hline & Statistic & Df & \multicolumn{1}{c|}{ Sig. } \\
\hline Pre Test & .981 & 3 & $\mathbf{. 7 3 9}$ \\
\hline Post Test & .980 & 3 & $\mathbf{. 8 0 6}$ \\
\hline a. Lilliefors Significance Correction \\
\hline
\end{tabular}

Berdasarkan tabel perhitungan uji normalitas di atas, diketahui bahwa nilai signifikasi pre-test 0,739>0,05, sementara nilai signifikasi post-test $0,806>0,05$ yang mana merujuk pada dasar pengambilan keputusan bahwa apabila nilai signifikasi $>0,05$ maka itu artinya data pre-test maupun post-test berdistribusi normal.

Sebab data yang diperoleh berdistribusi normal, maka teknik analisis data yang digunakan adalah uji paired sample t test. Berikut ini hasil analisis data dengan uji paired sample t test menggunakan SPSS 22:

\section{Tabel 5}

Hasil Analisis Uji Paired Sample T Test

\begin{tabular}{|c|c|c|c|c|c|c|c|c|}
\hline \multicolumn{7}{|c|}{ Paired Sample Test } & \multirow[b]{3}{*}{ df } & \multirow[b]{3}{*}{ Sig (2 tailed) } \\
\hline & \multirow[b]{2}{*}{ Mean } & \multirow{2}{*}{$\begin{array}{c}\text { Std. } \\
\text { Deviation }\end{array}$} & \multirow{2}{*}{$\begin{array}{l}\text { Std. } \\
\text { Error } \\
\text { Mean }\end{array}$} & \multicolumn{2}{|c|}{$\begin{array}{l}\text { 95\% Confidence } \\
\text { Interval of the } \\
\text { Difference }\end{array}$} & \multirow[b]{2}{*}{$\mathrm{T}$} & & \\
\hline & & & & Lower & Upper & & & \\
\hline $\begin{array}{c}\text { Pair } 1 \text { Pre Test- } \\
\text { Post Test }\end{array}$ & $4.433 \mathrm{E} 1$ & 9.45163 & 5.45690 & 20.85418 & 67.81249 & 8.124 & 2 & .015 \\
\hline
\end{tabular}

Berdasarkan hasil perhitungan paired sample t test di atas, maka dapat diketahui bahwa nilai Sig. (2 tailed) sebesar 0,015. Sesuai dengan dasar pengambilan keputusan $H_{a}$ diterima apabila nilai signifikan $<0,05$. Karena nilai $0,015<0,05$ maka $H_{a}$ diterima dan dapat disimpulkan bahwa terdapat perbedaan yang signifikan antara tingkat fanatisme terhadap idola pada pre-test dan post-test. Itu artinya konseling rational emotive behaviour efektif dalam menurunkan tingkat fanatisme terhadap idola pada penggemar K-Pop.

\section{PEMBAHASAN}

Berdasarkan hasil pre-test yang dilakukan di kelas XII-IPA 3, diketahui bahwa terdapat tiga siswa penggemar K-Pop yang memiliki tingkat fanatisme yang tinggi terhadap idola. Penggemar K-Pop pada umumnya memang di kenal sebagai penggemar yang fanatik terhadap idolanya. Hal ini sesuai dengan pendapat 
Tartila (2013) yang mengatakan bahwa para penggemar K-Pop sering dipandang dengan stereotip negatif, sebab mereka menggemari idolanya dengan cara yang berlebihan dan cenderung tidak wajar. Ketiga siswa dengan tingkat fanatisme yang tinggi tersebut, kemudian diberikan perlakuan berupa konseling rational emotive behaviour teknik cognitive disputation untuk menurunkan tingkat fanatisme terhadap idola yang dialaminya.

Konseling rational emotive behaviour dirasa cocok diterapkan pada subjek yang memiliki tingkat fanatisme yang tinggi. Konseling ini menurut Latipun (2008) bertujuan untuk mengubah pemikiran irasional individu menjadi pemikiran yang lebih rasional, sebab permasalahan individu bersumber dari pemikiran irasional yang dimilikinya. Berkaitan dengan hal ini, Mubarok (2006) mengatakan bahwa orang yang memiliki fanatisme dalam dirinya itu cenderung berpikir irasional. Fanatisme dapat menghilang ketika individu tersebut sudah bisa merubah pemikiran irasionalnya menjadi pemikiran yang rasional. Ada keterkaitan yang jelas di sini, antara konseling rational emotive behaviour dengan cara menghilangkan fanatisme dalam diri seseorang. Orang yang fanatik harus dirubah pemikiran irasionalnya menjadi pemikiran yang lebih rasional. Sementara konseling rational emotive behaviour membantu individu mengubah pikiran irasionalnya menjadi pemikiran yang rasional. Ketika orang yang memiliki fanatisme dalam dirinya diberikan konseling rational emotive behaviour, itu artinya orang tersebut dibantu untuk mengubah pikiran irasionalnya yang menyebabkan dirinya fanatik, menjadi pemikiran yang lebih rasional. Sehingga, ketika sudah mampu berpikir rasional, maka fanatismenya akan menghilang. Berdasarkan hal inilah, konseling rational emotive behaviour digunakan untuk membantu ketiga subjek menurunkan tingkat fanatisme terhadap idola dalam dirinya.

Saat proses konseling, tepatnya pada pertemuan kedua, peneliti melakukan identifikasi terhadap masalah yang dialami subjek berkaitan dengan fanatisme terhadap idola yang dialami. Peneliti menganalisis permasalahan subjek sesuai dengan konsep A-B-C. Menurut Latipun (2008) A (antecedent event) adalah peristiwa pendahulu yang memicu munculnya B (belief). Belief sendiri diartikan sebagai sebuah keyakinan yang rasional (rB) ataupun keyakinan yang irasional (iB). Sementara C (consequence) menurut Winkel dan Hastuti (2004) adalah akibat yang ditimbulkan oleh B (belief) yang berupa reaksi emosional dan perilaku. Berdasarkan cerita subjek tentang permasalahannya, peneliti menemukan beberapa pikiran irsional subjek tentang idolanya, dan bagaimana pemikiran irasional ini terbentuk serta dampaknya terhadap perasaan dan tingkah laku subjek. Hal ini sesuai dengan pendapat Winkel dan Hastuti (2004) yang mengatakan bahwa keterkaitan antara A-B-C akan menjadi jelas ketika proses konseling berlangsung dan konselor akan menemukan hubungan antar ketiganya.

Subjek ES berpikiran bahwa seorang penggemar harus membela idolanya yang dihina (Irasional Belief). ES berpikiran seperti ini karena menurut pengalaman ES hatters semakin gencar menghina idolanya ketika ES memilih diam dan mengacuhkan komentar yang berisi hinaan tersebut (Antecedent Event). Pemikiran tersebut pada akhirnya membuat ES merasa tersinggung, marah, sakit hati dan bahkan tidak segan-segan untuk bertengkar dengan hatters demi membela idolanya (Consequence). Apa yang dialami oleh ES ini, sesuai dengan pendapat Suroso dalam Eliani (2018) yang mengatakan bahwa fanatisme dalam diri seseorang dianggap sebagai penyebab munculnya perilaku egresif dan fanatik, seperti pertengkaran dan perkelahian.

Sementara subjek SK berpikiran bahwa seorang penggemar telah gagal menjadi penggemar apabila tidak menonton konser idolanya secara langsung. SK juga berpikiran bahwa pengorbanan terbesar yang bisa dilakukan oleh seorang penggemar untuk idolanya adalah dengan menonton konser. Dua pemikiran ini adalah pemikiran irasional SK tentang Idolanya (Irational Belief). Peristiwa pendahulu yang menyebabkan SK berpikiran seperti ini adalah gagalnya SK menonton konser idolanya di Indonesia pada tahun 2016 lalu. Oleh karena itulah SK rela melakukan apa saja untuk bisa menonton konser idolanya tahun ini yang rencananya akan kembali di gelar di Indonesia. Hal ini merupakan consequence dari pemikiran irasional yang dimiliki oleh SK. Menurut Marimaa (2011) apa yang dialami oleh SK tersebut menunjukkan salah satu ciri fanatisme, yaitu pengabdian pada tujuan. Sebab, menurut Marimaa, seorang penggemar bintang pop dapat menghabiskan seluruh uang tabungannya hanya untuk menyaksikan konser idolanya.

Lain halnya dengan subjek RS, yang berpikiran bahwa idolanya akan meninggalkannya ketika telah memiliki kekasih. RS juga berpikiran bahwa idolanya adalah miliknya. Pemikiran irasional RS muncul sebab RS sering melihat banyaknya idola lain yang tidak perduli lagi pada penggemarnya ketika sudah memiliki kekasih. Pemikiran irasional RS tersebut juga pada akhirnya membuat RS merasa sangat sedih, patah hati bahkan sampai membenci artis yang dikabarkan dekat dengan idolanya dan melontarkan komentar bernada negatif di sosial media terhadap artis yang bersangkutan. Hal ini sesuai dengan pengamatan yang dilakukan oleh Yusron (2009) terhadap salah satu penggemar K-Pop. Menurut Yusron penggemar K-Pop pada umumnya merasa bahwa idolanya adalah milik mereka. Hal ini menyebabkan para $K$-Popers tidak suka apabila idolanya menjalin hubungan istimewa dengan siapapun.

Pemikiran-pemikiran irasional setiap subjek selanjutnya berusaha dirubah oleh peneliti dengan cara mengajukan pertanyaan-pertanyaan yang menentang dan mengarahkan subjek untuk berfikir secara rasional (Winkel dan Hastuti, 2004). Kaitannya dengan hal ini, peneliti menggunakan teknik cognitive disputation untuk 
menentang pikiran irasional subjek penelitian. Menurut Komalasari (2018) teknik ini adalah teknik yang digunakan untuk menentang pikiran irasional seseorang dengan cara bertanya. Pertanyaan-pertanyaan yang ada dalam teknik ini diantaranya seperti pertanyaan untuk melakukan disput logis (menentang kelogisan pikiran irasional konseli), pertanyaan untuk reality testing (menguji kesesuaian pikiran tersebut dengan keadaan nyata), serta pertanyaan untuk pragmatic disputation (mempertanyakan manfaat pikiran tersebut bagi konseli). Ketiga subjek kemudian ditentang pemikiran irasionalnya dengan pertanyaan-pertanyaan yang digunakan dalam teknik cognitive disputation tersebut.

Proses menentang pikiran irasional ketiga subjek penelitian bukanlah mudah untuk dilakukan. Hal ini dikarenakan setiap orang menurut Winkel dan Hastuti (2004) cenderung mempertahankan keyakinan atau pemikirannya yang sebenarnya irasional dan cenderung pula memperkuat pemikiran tersebut dengan berbagai dalih. Selaras dengan pendapat ini, Goddard dalam Eliani (2018) juga menambahkan bahwa orang yang fanatik cenderung akan melakukan segala hal untuk mempertahankan keyakinannya. Kedua pendapat ini benar adanya, sebab ketiga subjek penelitian tidak serta merta setuju dengan pendapat peneliti. Saat proses mendebat mereka mereka tidak ragu untuk mengutarakan pendapatnya demi mempertahankan apa yang diyakininya selama ini. Namun seiring berjalannya proses debat, dan berbagai pertanyaan yang diajukan oleh peneliti pada akhirnya membuat ketiga subjek perlahan menyadari bahwa pemikirannya memang irasional dan sama sekali tidak ada gunanya untuk dipertahankan.

Selesainya proses menentang pikiran irasional, peneliti pun membawa konseli pada tahap selanjutnya, yaitu mengajarkan subjek untuk membentuk suatu pemikiran baru yang lebih rasional. Setelah diarahkan oleh peneliti ES mulai berpikiran bahwa seorang penggemar yang baik harus menerima segala kritikan tentang idolanya, sebab ES tidak bisa memaksa semua orang untuk menyukai idolanya. Peneliti juga meminta ES agar mengacuhkan saja hinaan hatters, karena bersikap demikian dirasa lebih bijak dalam menghadapi hatters idola. Sementara subjek SK mulai berpikiran bahwa apa yang akan dikorbankan olehnya nanti untuk menonton konser belum tentu sepadan dengan apa yang akan SK dapatkan. SK juga mulai berpikiran bahwa alangkah lebih baiknya jika uang yang sudah ditabung, dipergunakan untuk sesuatu hal yang lebih penting dibandingkan hanya menonton konser. Tidak jauh berbeda denga subjek RS yang juga sudah mulai berpikiran lebih rasional. RS menyadari bahwa idolanya bukanlah miliknya. Idolanya memiliki kehidupan sendiri dan sebagai penggemar yang baik sudah seharusnya RS mendukung setiap keputusan yang diambil idolanya, selama keputusan itu baik.

Peneliti pun memberikan tugas rumah pada masing-masing subjek untuk menerapkan pemikiran rasional tersebut dalam keseharian para subjek. Dampaknya cukup signifikan. ES mengatakan bahwa emosinya lebih terkontrol tatkala menghadapi hatters dan ES bisa bersikap acuh serta tidak mau meladeni hatters lagi seperti dahulu. Sementara subjek SK mengatakan bahwa setelah berpikiran secara rasional, keinginannya untuk menonton konser sudah tidak menggebu-gebu seperti dulu. Sementara subjek RS mengatakan sudah tidak sedih lagi, atau bahkan sakit hati apalagi menangis ketika idolanya dirumorkan memiliki kekasih. RS juga menyesal telah berkomentar buruk di sosial media dan berjanji untuk tidak mengulanginya kembali. Apa yang dialami oleh ketiga subjek sesuai dengan pendapat Winkel dan Hastuti (2004) bahwa diskusi yang dilakukan (menentang dan membentuk pikiran baru yang lebih rasional) akan memberikan efek-efek berupa pikiran yang lebih rasional, perasaan yang lebih wajar, dan perilaku yang lebih sesuai.

Setelah semua tahapan konseling rampung dilaksanakan, peneliti melakukan post-test untuk mengukur tingkat fanatisme masing-masing subjek penelitian setelah diberikan perlakuan. Hasil post-test menunjukkan bahwa masing-masing subjek penelitian mengalami penurunan tingkat fanatisme terhadap idola. Selanjutnya, hasil pre-test dan post-test dianalisis dengan menggunakan uji Paired Sample T Test sebab data yang diperoleh berdistribusi normal. Setelah dilakukan analisis perhitungan uji paired sample t test diketahui bahwa nilai signifikasi sebesar 0,015. Berdasarkan pengambilan keputusan, $H_{a}$ diterima apabila nilai signifikasi $<0,05$ dan $H_{a}$ ditolak apabila nilai signifikasi $>0,05$. Dikarenakan $0,015<0,05$ maka $H_{a}$ diterima dan itu berarti terdapat perbedaan atau perubahan tingkat fanatisme terhadap idola antara sebelum maupun sesudah pemberian perlakuan. Sehingga dapat disimpulkan bahwa konseling rational emotive behaviour teknik cognitive disputation mampu menguraangi tingkat fanatisme terhadap idola.

Kendala atau hambatan yang peneliti hadapi pada saat pelaksanaan kegiatan konseling berkaitan dengan waktu pelaksanaan kegiatan konseling. Kendala ini disebabkan oleh beberapa hal, diantaranya adalah ketiadaan jam BK di MAN 2 Gresik, serta padatnya jadwal masing-masing subjek penelitian yang merupakan siswi kelas XII. Dua hal ini membuat peneliti sedikit mengalami kesulitan dalam mengatur waktu untuk pelaksanaan kegiatan konseling.

Berdasarkan pemaparan hasil penelitian di atas, maka dapat disimpulkan bahwa konseling rational emotive behaviour teknik cognitive disputation telah terbukti dapat mengurangi tingkat fanatisme terhadap idola pada penggemar K-Pop. Sebab, di dalam proses konseling, subjek penelitian dibantu untuk merubah pemikirannya yang irasional menjadi pemikiran yang lebih rasional. Menurut Nugraini (2016) dalam penelitiannya mengatakan 
bahwa fanatisme mempengaruhi diri penggemar secara internal, lewat ketidaktepatan emosi dan cara berpikir yang tidak rasional.

Saat proses konseling, tepatnya pada pertemuan kedua, peneliti mengidentifikasi pemikiran irasional setiap subjek. Kemudian pada pertemuan ketiga, hasil identifikasi tersebut dipaparkan kepada subjek dan pada pertemuan keempat subjek diajak untuk mendebat pemikiran irasionalnya. Kegiatan mendeba dilakukan dengan tujuan agar subjek menyadari bahwa pemikirannya irasional. Pertemuan kelima, subjek yang sudah menyadari bahwa pemikirannya irasional diajak untuk mengembangkan pemikiran baru yang lebih rasional.

Fanatisme dikatakan akan menghilang apabila seorang yang fanatik sudah mampu berfikir rasional (Mubarok, 2006). Untuk membuktikan pendapat ini, peneliti memberikan angket post-test kepada subjek penelitian yang sudah mampu berpikir rasional selama proses konseling. Berdasarkan hasil post-test yang dibandingkan dengan hasil pre-test diketahui bahwa masing-masing subjek mengalami penurunan tingkat fanatisme terhadap idola. Hal ini membuktikan bahwa proses konseling rational emotive behaviour teknik cognitive disputation yang diberikan mampu menurunkan tingkat fanatisme terhadap idola setiap subjek.

Hasil penelitian ini juga mendukung penelitian yang dilakukan oleh Khulafaurosyidin (2013) yang menghasilkan kesimpulan bahwa konseling rational emotive behaviour dapat mengurangi tingkat fanatisme terhadap idola. Khulafaurosyidin mengurangi tingkat fanatisme terhadap idola dengan cara yang sama yaitu menelaah dan mencari pikiran-pikiran irasional subjek penelitian dan mengubahnya menjadi pikiran yang lebih rasional. Dengan melakukan hal tersebut, subjek penelitiannya mengalami penurunan tingkat fanatisme terhdap idola. Hal ini menunjukkan bahwa konseling rational emotive behaviour efektif apabila digunakan untuk membantu orang yang fanatik menurunkan tingkat fanatismenya.

\section{SIMPULAN DAN SARAN}

Penelitian ini dilakukan untuk menguji apakah konseling rational emotive behaviour dapat mengurangi tingkat fanatisme terhadap idola yang dialami oleh siswa penggemar K-Pop di MAN 2 Gresik. Setelah dilakukannya pre-test dan post-test pada 3 siswi kelas XII IPA 3 yang menjad subjek penelitian, diketahui bahwa terdapat penurunan tingkat fanatisme terhadap idola antar hasil pre-test dan post-test. Data pre-test dan post-test kemudian dianalisis dengan bantuan SPSS versi 22, diketahui bahwa nilai signifikasi sebesar 0,015. Berdasarkan pengambilan keputusan, $H_{a}$ diterima apabila nilai signifikasi $<0,05$, dan $H_{a}$ ditolak apabila nilai signifikasi > 0,05. Dikarenakan $0,015<0,05$ maka $H_{a}$ diterima dan itu berarti terdapat perbedaan atau perubahan tingkat fanatisme terhadap idola antara sebelum dan sesudah pemberian perlakuan. Sehingga dapat disimpulkan bahwa konseling rational emotive behaviour tenik cognitive disputation mampu mengurangi tingkat fanatisme terhadap idola.

Bagi guru BK diharapkan penelitian ini dapat menambah wawasan, juga masukan, serta dapat menjadian konseling rational emotive behaviour sebagai salah satu penanganan alternatif dalam membantu siswa yang memiliki permasalahan yang sama. Sementara bagi peneliti selanjutnya yang ingin melakukan penelitian yang serupa, diharapkan mampu untuk mempertimbangkan setting konseling yang hendak dilakukan, yaitu berupa konseling kelompok.

\section{DAFTAR RUJUKAN}

Eliani, J. (2018). Fanatisme dan Perilaku Agresif Verbal di Media Sosial pada Penggemar Idola K-Pop. Jurnal Penelitian Psikologi, 3(1), 59-72.

Fitriani, N. (2016). Penerapan Teknik Dispute Cognitive Dalam REBT untuk Meningkatkan Resiliensi pada Mahasiswa ( Single Subject Research terhadap mahasiswa Program Studi Psikologi Angkatan 2014 Fakultas Ilmu Pendidikan Universitas Negeri Jakarta ) PENDAHULUAN. Jurnal Bimbingan Dan Konseling, 5(1), 73-80.

Gafar, A. (2014). Kemampuan Menceritakan Tokoh Idola dengan Media Gambar. Jurnal Pena, 4(1), $13-23$.

Khulafaurosyidin, A. F. (2013). Penerapan Konseling Rasional Emotif Perilaku untuk Mengurangi Tingkat Fanatisme terhadap Idola pada Siswa SMPN 6 Tuban Program Studi S1 Bimbingan dan Konseling UNESA. Surabaya: PPs Universitas Negeri Surabaya.

Komalasari, G. (2018). Teori dan Praktik Konseling. Jakarta: PT.Indeks.

Kurniati, A., \& dkk. (2015). Dampak Demam Virus Korea Terhadap Identitas Diri Remaja. Jurnal Transformasi, 11(1), 54-59.

Latipun. (2008). Psikologi Konseling. Malang: UMM Press. 
Marimaa, K. (2011). The many faces of fanaticism. Journal of ENDC Proceedings, 14, 29-55.

Pertiwi, S. A. (2013). Konformitas dan Fanatisme Pada Remaja Korean Wave (Penelitian pada Komunitas Super Junior Fans Club ELF “Ever Lasting Friend”) di Samarinda. Journal Psikologi, 1(2), 157-166.

Prakoso, A. S. (2013). Fanatisme Supporter Sepak Bola ditinjau dari Tingkat Pendidikan. Surakarta: Universitas Muhammadiyah Surakarta.

Tartila, P. L. (2013). Fanatisme fans kpop dalam blog netizenbuzz. Jurnal Sosial Dan Hukum, 2(3), 190-250.

Winkel, W.S, dan Hastuti, S. (2004). Bimbingan dan Konseling di Institusi Pendidikan. Jakarta: Gramedia Widiasarana.

Yusuf, Syamsu, L. . (2014). Psikologi Perkembangan Anak dan Remaja. Bandung: PT. Remaja Rosdakarya.

Yusron, Atmi Ahsani, 2009, “Fangirls”. (online), (http://www.slideshare.net/RonzzyKevin/psikologikomunikasi-perilaku-fans, diakses pada tanggal 25 September 2018). 